\title{
MINERAL RESOURCE POTENTIAL OF THE RYAN HILL, ROADLESS AREA, SOCORRO COUNTY, NEW MEXICO
}

\author{
By \\ Charles H. Maxwell and Allen V. Heyl, U.S. Geological Survey, \\ and \\ Clarence E. Ellis and David C. Scott, U.S. Bureau of Mines
}

\section{STUDIES RELATED TO WILDERNESS}

Under the provisions of the Wilderness Act (Public Law 88-577, September 3, 1964) and related acts, the U.S. Geological Survey and the U.S. Bureau of Mines have been conducting mineral surveys of wilderness and primitive areas. Areas officially designated as "wilderness," "wild," or "canoe" when the act was passed were incorporated into the National Wilderness Preservation System, and some of them are presently being studied. The act provided that areas under consideration for wilderness designation should be studied for suitability for incorporation into the Wilderness System. The mineral surveys constitute one aspect of the suitability studies. The act directs that the results of such surveys are to be made available to the public and be submitted to the President and the Congress. This report discusses the results of a mineral survey of the Ryan Hill Roadless Area (03008), Cibola National Forest, Socorro County, New Mexico. Ryan Hill Roadless Area was classified as a recommended wilderness area during the Second Roadless Area Review and Evaluation (RARE II) by the U.S. Forest Service, January 1979. Part of the Ryan Hill Roadless Area was later designated the Languir Research Site by Public Law 96-550, 1980.

\section{MINERAL RESOURCE POTENTIAL SUMMARY STATEMENT}

The numerous productive mines, mineral deposits, and occurrences near the periphery of the Ryan Hill Roadless Area are indications of low to high mineral resource potential for manganese and base- and preciousmetals within the study area. There is a moderate to high potential for manganese deposits along the eastern and southeastern sides of the roadless and adjacent study area. The potential for the occurrence of manganese and base and precious metals is low to moderate along parts of the north, south, and west perimeter of the study area.

\section{INTRODUCTION}

A mineral survey of the Ryan Hill Roadless Area and adjacent areas was made in 1980-81 by the U.S. Geological Survey and the U.S. Bureau of Mines. The study area (fig. 1) comprises about $69 \mathrm{sq} \mathrm{mi}(44,000$ acres) in the Magdalena Ranger district of Cibola National Forest, Socorro County, N. Mex.; and is a composite of all the areas recommended for study. It is located in the southern part of the Magdalena Mountains at altitudes ranging from about $6,400 \mathrm{ft}$ along the southern boundary to a maximum of 10,783 $\mathrm{ft}$ at South Baldy Peak. Local relief of 1,000-2,000 ft is common. The Ryan Hill Roadless Area was withdrawn from RARE II classification and part of it was reestablished as the Langmuir Research Site by Public Law 96-550, December 19, 1980. The Langmuir Research Site occupies about $48 \mathrm{sq} \mathrm{mi}$ within the study area. The Langmuir Laboratory is situated south of South Baldy Peak, in the northwestern corner of the research site, at altitudes of $10,500-10,600 \mathrm{ft}$. The laboratory is engaged in research on lightning and other atmospheric conditions and on astronomical phenomena.

The Langmuir Laboratory is accessible by Forest Service Road 235 from U.S. Highway 60; the junction is about $15 \mathrm{mi}$ west of Socorro and $10 \mathrm{mi}$ east of Magdalena. Access to the periphery of the roadless area is provided by unimproved ranch and mine roads and jeep trails that branch from State Highway 107 and Interstate 25.

Fieldwork was conducted by the authors during 1980-81. The generalized geologic map (fig. 2) is modified from previous work done in the area by Osburn (1978), Allen (1979), Petty (1979), Bowring (1980), Osburn and others (1982), and Roth (1981) as well as the current fieldwork. This fieldwork consisted of limited geologic mapping and of geochemical sampling of selected stream sediments, mineralized areas, veins and bedrock, and panned concentrates of stream 


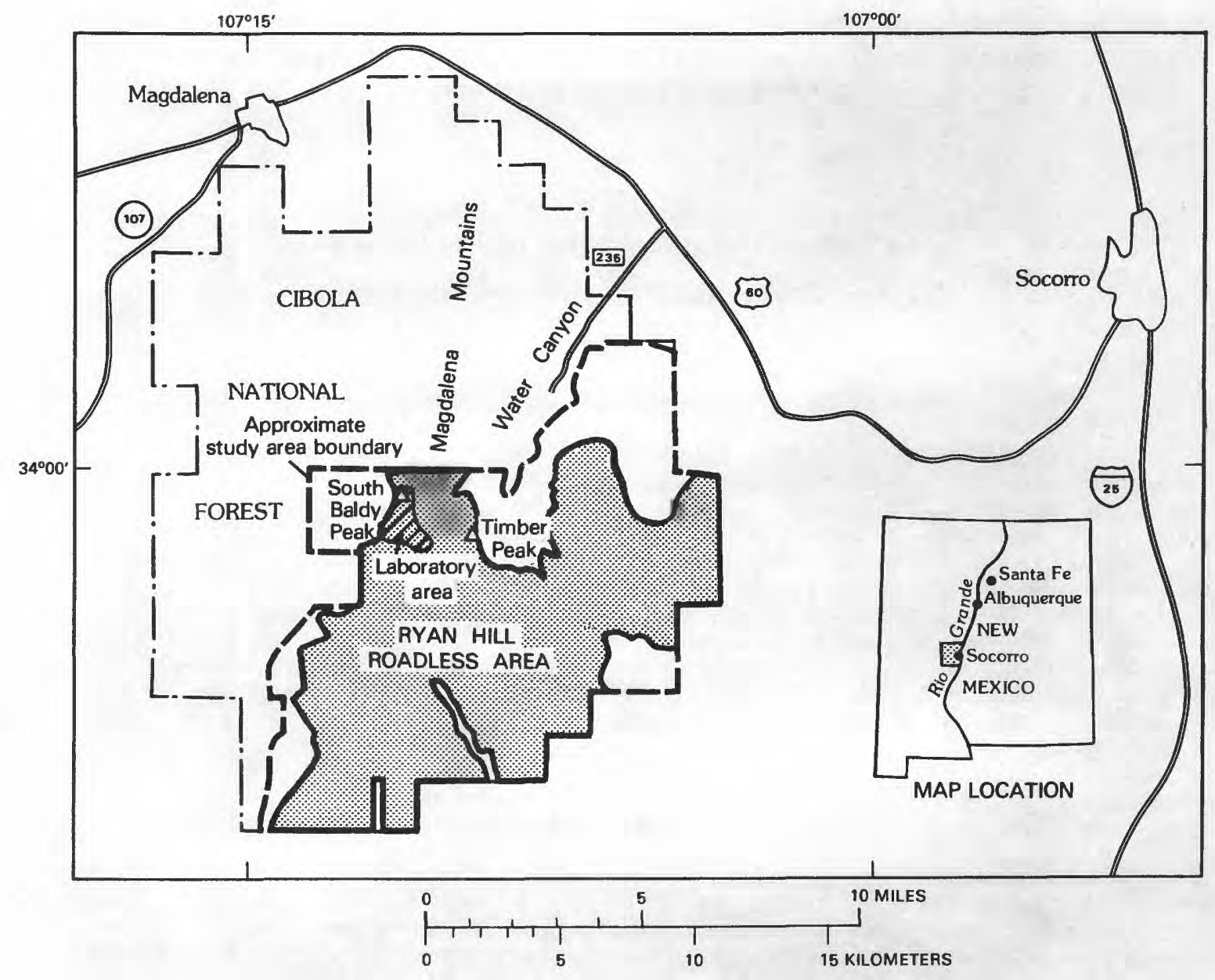

Figure 1.-Index map of the Ryan Hill Roadless Area and adjacent study area, Socorro County, New Mexico. 
sediments from selected drainages. Major mines and prospects were studied and sampled, and a search was made for mining claim location notices in the Socorro County Courthouse (Ellis and Scott, 1982).

\section{Mining activity}

Although there was no mining activity in the Ryan Hill Roadless Area at the time fieldwork was conducted, limited mining activity was observed $2.4 \mathrm{mi}$ outside the roadless area in the northern part of the Water Canyon mining district. A small gold property was being worked intermittently at the head of Copper Canyon, $2.5 \mathrm{mi}$ outside the roadless area in the Magdalena district. Courthouse records show that some mining claims have recently been located near the roadless area.

\section{GEOLOGY, GEOCHEMISTRY, AND GEOPHYSICS}

\section{Geology}

The southern part of the Magdalena Mountains, which includes the Ryan Hill Roadless Area, comprises part of a deeply eroded composite volcano composed predominantly of intensely welded, rhyolitic, ash-flow tuffs; rhyolite flows and flow domes; and minor quartz latite and dacite flows, overlying and interlayered with andesite flows and lahars. Monzonite intrusives occur in the northern part of the roadless area, and some Precambrian and Paleozoic rocks occur just outside the area in and north of Water Canyon. The volcanic rocks generally dip radially away from the area of South Baldy Peak. Older rhyolite and rocks of intermediate composition (andesite to latite) in the central part of study area range in age from 38 to 26 million years (m.y.); younger rhyolite and intermediate rocks are about $14 \mathrm{~m} . \mathrm{y}$. old in the northwesternmost part and $11 \mathrm{~m} . \mathrm{y}$. old along the eastern edge of the area. The area is complexly faulted in a rectilinear pattern with both normal and reverse faults trending predominantly north-northwest or east-northeast. Most fault blocks dip eastward; some in the western part of the area dip westward.

The oldest volcanic rocks in the study area are andesite flows, tuffs, and lahars, exposed around South Baldy Peak. They interfinger with and are overlain by rhyolite and latite flows and intensely welded ash-flow tuffs. Most of the andesite is composed of variegated purple, brown, and gray, fine-grained, relatively homogeneous pyroclastic deposits and minor flows that have been subjected to propylitic and argillic alteration. Less altered flows occur locally and are dark gray brown and porphyritic with plagioclase phenocrysts and small pyroxene crystals in a fine-grained groundmass. Lahars, common near contacts with the overlying rhyolites, contain blocks varying in size from a few inches to a foot or more across. These blocks are composed mostly of andesite and basalt but also contain minor clasts of Precambrian and Paleozoic rocks and flow-banded rhyolite or latite.

Older rhyolite and latite flows and ash-flow tuffs make up most of the exposures in the area, forming cliffs and steep slopes, and capping most of the ridges and peaks. In addition, they are usually intensely welded and produce extensive talus deposits on steep slopes which largely obscure the underlying rocks. The ash-flow tuffs occur as a series of flow units 0-600 ft thick, that range from crystal-rich to crystal-free, and are intensely to poorly welded. The porphyritic or crystal-rich rhyolites are composed of sanidine, quartz, biotite, plagioclase, and magnetite in a glassy groundmass; the quartz latite is composed of plagioclase, quartz, biotite, sanidine, and hornblende in a glassy groundmass. The minor crystal-free units commonly have prominent spherulites. The densely welded units are locally interbedded with poorly welded air-fall tuffs, tuffaceous sandstones, and thin andesite or basaltic andesite flows and layers of mafic scoria.

The eastem part of the roadless area is complexly faulted in a rectilinear pattern of normal and reverse faults trending north-northwest and eastnortheast. Most of the faults are down to the west, and the blocks between faults are tilted eastward. Faulting in the western part of the area appears to be less complex but exposures are poor in the vastly thicker rhyolite units and many faults may not be evident. Some of the faults in the northern part of the area trend generally north-south and commonly are mineralized.

\section{Geochemistry}

A total of 373 vein and mineralized rock samples were taken from all veins and mineralized areas encountered during the 1980-81 field season. Streamsediment samples were collected from 186 selected drainage basins in and around the roadless area; in addition, 9 concentrates from stream sediments were panned from the major drainages in order to locate any hidden areas of anomalous mineralization.

Samples of manganese veins in and outside the southeastern and southwestern parts of the roadless area were collected from outcrops, prospects, and opencut mines. Many elements besides manganese are present in anomalously large amounts in most or all samples. Barium is present in large amounts. The most common manganese minerals, hollandite and psilomelane, both contain barium. Other elements present in anomalously large amounts are arsenic, beryllium, cobalt, copper, molybdenum, antimony, vanadium, lead, and zinc. Lanthanum content is three times greater than the regional normal, strontium is also high, and tungsten is present in amounts approaching ore grade.

The suite of elements in the mineralized rock samples from the northern part of the roadless area contrast markedly with those from the rest of the area. Samples from the small veins around South Baldy Peak and from a mine on the northern boundary show as much as $10 \mathrm{oz}$ silver/ton, large amounts of copper and manganese, and anomalously high lead, zinc, and bismuth; notably absent in detectable amounts were molybdenum, tungsten, barium, arsenic, antimony, and cobalt. Other samples from veins in the Water Canyon mining district have similar values but in addition have anomalously high molybdenum and gold.

\section{Geophysics}

Charts of the residual magnetic intensity of the region were prepared for this project. Contours of the total intensity magnetic field indicate a relatively featureless zone in the central and southwestern part 
of the area, ranging generally from -20 to +20 gammas. An arcuate 200 gamma ridge occurs near Mill Canyon, the Langmuir Laboratory site, and Timber Peak and a sharp circular high of 240 gammas occurs near Ryan Hill Canyon on the southeast edge of the area. A small east-west ridge of 140 gammas near Sixmile Canyon swings northward toward the mouth of Water Canyon, a very steep drop to the northeast to a low of -80 gammas at the northeast corner of the area. A deep circular low of -700 gammas is situated about 2 mi north of South Baldy Peak.

Two audio-magnetotelluric profiles were made by D. L. Hoover (unpub. data, 1982) in the eastern part of the roadless area, one along Sixmile Canyon and another from Madera Canyon southward. The audiomagnetotelluric profiles show a zone of greatly reduced resistivity ( 1 or 2 orders of magnitude) from 300 to $900 \mathrm{ft}$ below the surface to a depth of $2,400-$ $3,500 \mathrm{ft}$, in an area generally corresponding to ground containing numerous veins and mineral occurrences. The low resistivity could indicate the presence of sulfides in the rocks or the presence of mineralized water. These data, along with the unusually high concentrations of accessory elements in the manganese deposits, suggest the possibility of the continuation of an extensive epithermal vein system at depth, possibly containing base-metal deposits.

\section{MINING DISTRICTS AND MINERALIZED AREAS}

Portions of two mining districts are located in and near the roadless area. The Magdalena Mountains manganese district (File and Northrop, 1966) trends north-northeast on the southeastern flank of the Magdalena Mountains and is about $8 \mathrm{mi}$ long and $3 \mathrm{mi}$ wide. The Water Canyon mining district (File and Northrop, 1966) is located in Water Canyon in the $\mathrm{S} 1 / 2$, T. 3 S., R. $3 \mathrm{~W}$, district is about $3 \mathrm{mi} \mathrm{wide,} \mathrm{and}$ follows the course of Water Canyon for about $4 \mathrm{mi}$. Located $1 \mathrm{mi}$ south of the Water Canyon mining district is the Big Timber mineralized area.

\section{Water Canyon mining district and vicinity}

Also known as the Silver Mountain district, the Water Canyon mining district is located on the northeast edge of the roadless area and is drained by Water Canyon, Copper Canyon, and North Fork Canyon. Although extensive exploration has been done in the district, there has been little known production. Only the workings in the southeast part of the district which are inside or adjacent to the roadless area are discussed in this report. The district is reached via the Water Canyon road, which is approximately $9 \mathrm{mi}$ southeast of Magdalena on U.S. Highway 60.

Prospecting in the Water Canyon mining district began in 1868, at the same time the lead-zinc mines were opened in the Magdalena district to the north (Jones, 1904). Two periods of mining occurred in the district; the first from 1868 to 1917 and the second from about 1929 to 1946 . Sporadic mining activity continues today in the district.

Although there are no patented mining claims in the part of the district that overlaps with the roadless area, two patented mining claims, the Buckeye and the Hall Lyten, are located approximately $1 \mathrm{mi}$ from the roadless area. The Buckeye mine was the major producer in the district; however, the quantity of copper ore shipped is unknown. Three unpatented claims are on the northwest edge of the roadless area and more than 200 claims are located within $1 \mathrm{mi}$ of the roadless area. Workings on the claims consist of shaft, adits, and prospect pits, which explore a limestonegreenstone contact; a sill of andesite intrudes Precambrian greenstone, which underlies Paleozoic limestone. Assay results from this area show that minor amounts of gold, lead, manganese, silver, and zinc occur along the limestone-greenstone contact and in fractures in the limestone. The few workings in the roadless area are small pits and short adits, with similar mineral occurrences.

Barite was found in a vein in a small open pit in sec. 34 , T. 3 S., R. $3 \mathrm{~W}$. The 2 - to 3 -ft-thick vein trends N. $60^{\circ}$ W. away from the roadless area and is exposed for only about $200 \mathrm{ft}$. Assay results show about 1.0 percent barium present in each of two samples taken from the vein.

Minor amounts of gold and silver, and associated copper, lead, zinc, and molybdenum, occur in shear zones near the southeastern part of the Water Canyon mining district. Samples from small veins around South Baldy Peak show large amounts of silver (as much as $10 \mathrm{oz} /$ ton), copper, and manganese, and anomalously high lead, zinc, and bismuth contents.

\section{Big Timber mineralized area}

Approximately $1 \mathrm{mi}$ south of the Water Canyon mining district is the Big Timber mineralized area, where the Big Timber mine is located. Two adits and several prospect pits and trenches explore a nearvertical fault zone in a rhyolite dike. Sample assay results from the mineralized area revealed trace amounts of gold, lead, silver, uranium, and zinc. A gamma-ray spectrometer was used to test for the uranium. The highest assay, 0.007 percent $\mathrm{U}_{3} \mathrm{O}_{8}$, was from the upper of the two adits (Ellis and Scott, 1982). One unpatented claim in the Big Timber mineralized area lies in the roadless area. Two patented claims and numerous unpatented claims are adjacent to this claim but are outside the roadless area.

\section{Magdalena Mountains manganese district}

The Magdalena Mountains manganese district is in the southeast part of the Magdalena Mountains, parallel with the eastern side of the range. Only that part of the district in and near the roadless area is discussed in this report.

The district was established about 1937 when three manganese claims known as the Niggerhead group were located (Farnham, 1961). Since that time, many claims have been located in a northeasterly direction along the eastern side of the range. In 1950, a manganese occurrence was discovered on the west slope of the range in sec. 34, T. 4 S., R. 4 W.; the Black Goose claims are considered part of the district. Mining in the district was sporadic from 1940 until 1959. Since that time, little activity has occurred in the district.

No patented mining claims are in the district. Approximately 240 unpatented claims have been located in the roadless area and an additional 300 claims located within a $2 \mathrm{mi}$ radius of the area according to courthouse records. 

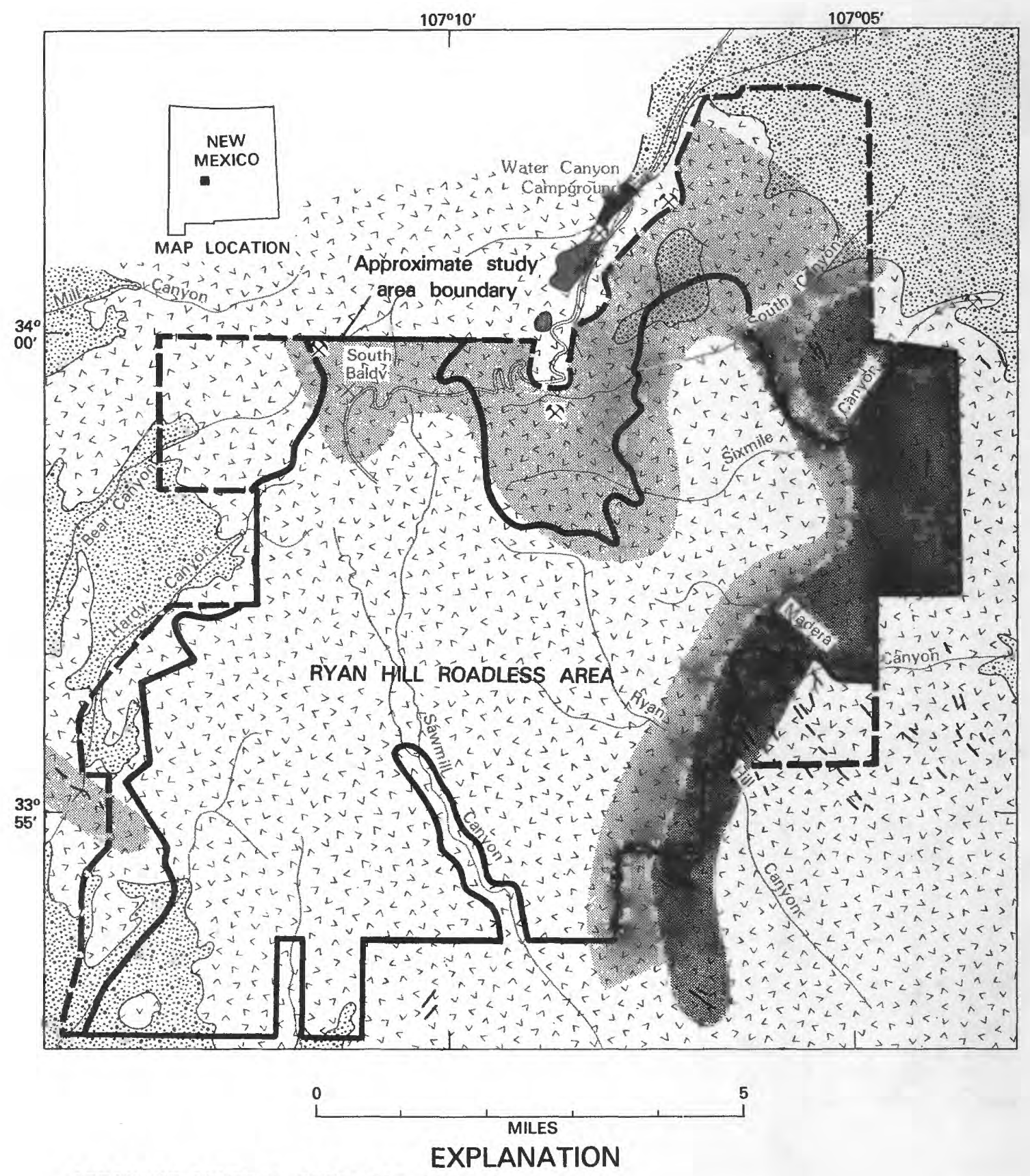

AREAS OF MINERAL RESOURCE POTENTIAL

Area with moderate to high resource potential for manganese in vein deposits

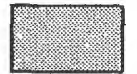

Area with low to moderate resource potential for manganese and base and precious metals in vein deposits

父 Mine
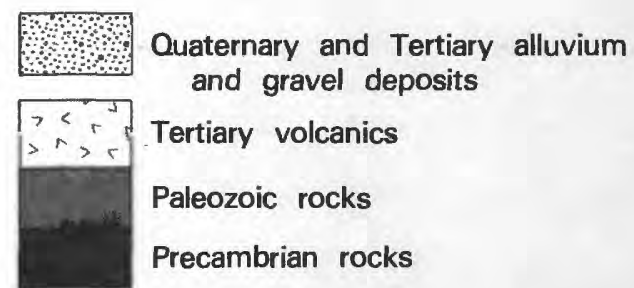

Tertiary volcanics

Paleozoic rocks

Precambrian rocks

Contact

\section{Maganese vein}

Figure 2.-Generalized geologic and mineral resource potential map of the Ryan Hill

Roadless Area and adjacent study area, New Mexico. 
The district has known production from several mines: Bear Canyon, Bianchi, Black-Eagle, Black Goose, Buena Vista, Burris, Combs and Wood, JVB, Lucky Ridge, Magnum, Manganese Chief, Manganese Queen, Niggerhead, Phillips lease, Rheinhart, and the West Niggerhead. Records show 8,171 tons of concentrate containing 34 percent manganese was produced from about 140,000 long tons of ore from this group of mines (Farnham, 1961). Large quantities of crushed rock used as road aggregate were produced from waste rock at some manganese mines in the district; however, tonnages are not available.

The Manganese Queen mine is geographically in the Water Canyon mining district, but is geologically part of the Magdalena Mountains manganese district. There is recorded production from the Manganese Queen mine during World War I, World War II, and the Korean conflict, unlike the rest of the mines in the manganese district.

Most of the manganese deposits occur as veins along persistent north- and northwest-trending faults and in short east- and northeast-trending faults, in brecciated zones 1-30 ft wide and as much as 2,000 ft long. The breccia zones are made up of layers of manganese oxides as much as several inches thick, which coat the walls and cement angular fragments of the host rock, and local lenses of solid manganese minerals that are several feet by several tens of feet in size. Jasperoid is locally prominent both in the veins and in the wallrock; black or white calcite is locally present in the veins.

The most abundant minerals in the manganese deposits are the barium manganates, hollandite and psilomelane; pyrolusite and cryptomelane were also identified. Spectrographic analyses of 60 samples from manganese veins in the roadless area show that the deposits contain large amounts of lead, zinc, copper, and molybdenum. Tungsten is noteworthy, and samples commonly contain 0.2 to 0.5 percent. Arsenic and antimony are also present in large amounts; other elements present in anomalously large amounts include beryllium, cobalt, lanthanum, strontium, and vanadium. Silver was not detected in most samples but gold was present (trace to 1 part per million) in many of the samples.

The manganese deposits appear to be epithermal, formed in the uppermost levels of a hydrothermal system near the original land surface; some manganese occurs as hot spring deposits. None of the manganese deposits in this area have been developed for more than a few tens of feet in depth, but similar deposits in the Luis Lopez district, $6 \mathrm{mi}$ to the east, have been mined to depths of $450 \mathrm{ft}$ or more. The low resistivity indicated by the audio-magnetotelluric profiles, along with the unusually large amounts of base metals and other accessory elements in the manganese deposits suggest the probability of the continuation of an extensive epithermal vein system at depth containing base- and possibly precious-metal deposits.

Most workings in the Magdelena Mountains manganese district are open pit. Some of the pits are several hundred feet long and expose numerous fracture zones and faults. Manganese is associated with these faults, fracture systems, and shear zones in rhyolite country rock. The Niggerhead mine is a typical example of one of the open pit mines where psilomelane and pyrolusite occur as thin coatings on fracture surfaces. The manganese coatings also occur around breccia fragments in shear zones and as thin seams and veinlets in the rhyolite. High-grade manganese is generally confined to shear and breccia zones and does not persist at depth. Calcite, iron oxides, and quartz occur with the manganese. The manganese oxides are argentiferous, but this was either not recognized or not reported during the periods of production. Extensive beneficiation was required to make a salable product from the low-grade manganese ore, and thus, the properties were mineable chiefly during war time and when the Federal government had a domestic manganese ore purchase program between 1951 and 1961. Assay results from this district show an average grade of 14.0 percent manganese (Ellis and Scott, 1982).

\section{ASSESSMENT OF MENERAL RESOURCE POTENTLAL.}

Numerous mineral deposits and occurrences have been identified near the periphery of the Ryan Hill Roadless Area. Manganese deposits are located along the eastern, southeastern, and southwestern side of the area and extend into the roadless area. The boundary of the roadless area was drawn to exclude patented claims and the most productive manganese mines, but many smaller mines and prospects, as well as additional occurrences that are too small in surface expression to have been prospected, occur within the area.

The potential for the occurrence of manganese resources is moderate to high along the eastern and southeastern sides of the area. The resource potential for manganese and the base and precious metals is low to moderate along much of the perimeter of the roadless area.

\section{REFERENCES}

Allen, Philip, 1979, Geology of the west flank of the Magdalena Mountains south of the Kelly mining district, Socorro County, New Mexico: New Mexico Bureau of Mines and Mineral Resources Open-File Report OF-119, 161 p.

Bowring, S. A., 1980, The geology of the west-central Magdalena Mountains, Socorro County, New Mexico: New Mexico Bureau of Mines and Mineral Resources Open-File Report OF-120, 135 p.

Ellis, C. E., and Scott, D. C., 1982, Mineral resource investigations of the Ryan Hill RARE II Further Planning Area, Socorro County, New Mexico: U.S. Bureau of Mines Open-File Report MLA 7882,17 p.

Farnham, L. L., 1961, Manganese deposits of New Mexico: U.S. Bureau of Mines Information Circular 8030, p. 131-171.

File, L., and Northrop, S. A., 1966, County, township, and range locations of New Mexico districts: New Mexico Bureau of Mines and Mineral Resources Circular 84, p. 34-36.

Jones, F. A., 1904, New Mexico Mines and Minerals, World's Fair edition: Santa Fe, The New Mexico Printing Company, p. 126.

Osburn, G. R., 1978, Geology of the eastern Magdalena Mountains, Water Canyon to Pound Ranch, 
Socorro County, New Mexico: New Mexico Bureau of Mines and Mineral Resources OpenFile Report OF-113, 159 p.

Osburn, G. R., Petty, D. M., and Chapin, C. E., 1982, Geology of the Molino Peak quadrangle: New Mexico Bureau of Mines and Mineral Resources Open-File Report OF-139A, 22 p.

Petty D. M., 1979, Geology of the southeastern Magdalena Mountains, Socorro County, New
Mexico: New Mexico Bureau of Mines and Mineral Resources Open-File Report OF-106, 174 p.

Roth, Susan, 1981, Geology of the Sawmill Canyon area of the Magdalena Mountains, Socorro County, New Mexico: New Mexico Bureau of Mines and Mineral Resouces Open-File Report OF-129, 96 p. 
